\title{
An Analysis of Lady Chatterley's Lover from the Perspective of Ecofeminism*
}

\author{
Ting Bo \\ Faculty of Foreign Languages, Huaiyin Institute of Technology, 223001, Jiangsu, China
}

\begin{abstract}
Eco-feminism, as a new theoretical criticism of literature, combines the oppression and domination of women. There is a critical connection between woman and nature, originating from their shared history of oppression by a patriarchal Western society. The development of eco-feminism has significant influence on attitudes of human beings toward nature, especially the relationship between nature and woman. Lawrence is well-known for both his unique writing techniques and frank expression of sex. In Lady Chatterley's Lover, Lawrence shows his strong awareness of eco-feminism by exploring the relations between man and man, nature and man, nature and woman.
\end{abstract}

Index Terms—Lady Chatterley's Lover, ecofeminism, nature, woman, harmonious relationship

\section{INTRODUCTION}

David Herbert Lawrence is an original and controversial English writer of the 20th century literature. Born on September 11,1885 and died in 1930 , Lawrence spanned from the late $19^{\text {th }}$ century to the early $20^{\text {th }}$ century when England became a highly industrialized country. However, the nature was greatly damaged because of the industrialization. The destruction of the natural landscape by the modern machines made him sad. This is why love and concern for nature becomes his major themes of his writings, aiming to arouse people's awareness of establishing a harmonious relationship with nature. The time Lawrence lived is the rise of the woman's movement in the United Kingdom. As a result, woman won more independence, leading their financially less dependence on their fathers and husbands. Therefore, the role and the status of women have undergone great changes, achieving more freedom and independence, even the right to peruse of love and sexual freedom.

As one of D. H. Lawrence's masterpieces, and his last novel, Lady Chatterley's Lover(1928), first published privately in 1928 in Florence, Italy, suffered opposite voices because of its descriptions about overt sexuality. The unabridged version was not published in Britain until 1960. Lady Chatterley's Lover (1928) tells a story about a young girl named Connie married Clifford Chatterley, a upper-class husband, who was paralyzed back from the First World War. They can not have a baby because of Clifford's paralysis. Clifford focuses on his coal-mine and making money, emotionally neglecting of his wife's feelings and finally leading to the distance between him and Connie. Then Connie met Oliver Mellors, the gamekeeper, in the woods and had affair with him. Clifford was unwilling to devoice with Connie when she was pregnant. They have no choice but to wait desperately.

In 1974, French feminist scholar Francoised' Faubonne puts forward the word "eco-feminism" in the "Feminist Destruction" for the first time. In her opinion, the oppression of woman and the oppression of nature have a direct link: the ecological problems are women's issues, and woman's issues are also the ecological problems. Therefore, she calls for an ecological movement to realize woman's leadership, establishing harmonious relationship between man and nature. Influenced by her, the movements of ecological feminism in the Western world sprung up. In the late 1970s and early 1980s, the development of eco-feminism was promoted by a series of serious ecological disaster. The main representatives of this theory include Karen. J. Warren, Charlene Spretnak, Caroly Merchant, Vandana Shiva and Maria Mies and others.

In terms of the relationship between woman and nature, eco-feminists have their unique viewpoints. By systematically analyzing the position of nature in the modem Western world, and the study of close links between woman and nature, they connect the woman's issues with the natural motion. They believe that woman resemble the same role with nature in a male-dominated society. Woman is forced to keep silent in public, and finally becomes second-class citizen. Therefore, eco-feminists struggle for liberation of both nature and woman.

In accordance with eco-feminist theory, Lawrence has a deep ecological awareness and feminist consciousness. Lady Chatterley's Lover, describing the close relationship between nature and woman, has shown Lawrence's ecological and feminist ideas. Lawrence presented the woman's oppression and struggle for love, sex and freedom in the novel. Janice $\mathrm{H}$. Harris hails Lawrence as "the voice of proclaiming a woman's liberation through the recognition of her sexual self."(Janice, 1990, p.70) According to Bridget Pugh, Lady Chatterley's Lovers embodies Lawrence's statement about a negation of the power-urge as industrialism similar to his theories in "Lawrence and Industrial symbolism".

\footnotetext{
* Fund project: An Ecofeminist Study on D.H. Lawrence’s Novels commissioned by Jiangsu Education Department (Project No.:2017SJB1629)
} 


\section{NATURAl ENVIRONMENT Is POLluted}

In the 1800s, industrial civilization emerged on a large scale in Britain, causing an unbalanced ecological system and bringing natural disasters on humans. Human society has been demanding more and more from the nature. As a result, the old beautiful landscapes have disappeared and been replaced by the sight of thick smoke and the buildings of factories. A series of problems between nature and man appear.

Nature is an indispensable part in Lawrence's works, unveiling his prophetic ecofeminist consciousness. In the nineteenth century, with the industrial revolution in full swing, the capitalist civilization was unprecedentedly prosperous. Human beings had extorted and plundered natural resources from nature infinitely in order to satisfy their survival and development. And they became the nature's master and nature becomes their servant instead. At the same time, the disaster brought by industrial civilization to the capitalist society was great. The thick forest and the green field are replaced by coal mine and factories, with the smoke from the chimney and the mechanical noise filling the air. The peaceful and harmonious countryside life is getting far away from the human. Due to the excessive exploitation of coal, many pits shut down and woods become deserted. What's worse, the human nature is suppressed, and the human spiritual world is gradually distorted. This is the background of Laurence's life. He is deeply aware of the deepening mental crisis in western society. He was bitter about the war and the industrial revolution, and was deeply disturbed and worried about the serious destruction of human nature by the industrial revolution.

The countryside named Wragby in Lady Chatterley's Lover is the illustration of the degeneration of nature. Lawrence described the era in the beginning of book as a "tragic age", showing his hatred to the destruction of industrialization to nature. Lawrence holds that humans and nature are closely connected with each other. As he declared in Lady Chatterley's Lover: "Ours is essentially a tragic age, so we refuse to take it tragically. They cataclysm has happened, we are among the ruins, we start to build up new little habits, to have new little hopes" (Lawrence, 2009, p.1) It is obvious that readers are told by him that nature suffers and degenerated, becoming "the ruins" as a result of the development of industrialization.

In the beginning of Chapter 2, Wragby is presented in such a picture: "Wragby was a long low old house in brown stone, begun about the middle of the eighteenth century. It stood on an eminence in a rather fine old park of oak trees, nearby." (Lawrence, 2009, p.11) This is the beautiful picture of Wragby, a tranquil and beautiful place covered with green trees and filled with pure air before the industrial revolution. But what people could only see is: "Tevershall pit with the chimney of cloud of steam and smoke, and in the damp, just distance original strange Tevershall mountain village-a village, backward, completely hopeless for a long and terrible miles. We can see: small begrimed masonry building with black roof cover rows of poor, sharp corners and deliberately blank and desolate." (Lawrence, 2009, p.11)

Nature has become the resource of materials for industrialization. The beautiful place had been made into an ugly one owing to industrialization. A sharp contrast between the ugliness and the beauty of Wragby can be seen as a disagreeable landscape, which Lawrence called "utter hopeless ugliness". The ruined nature is described in a detailed way by Lawrence. Connie is made into his spokesman, witnessing how nature has been destroyed by human beings arbitrarily. For example, Connie can hear tremendous noise from the greedy machine when staying in the quite room at Wragby, without wind at all. On the contrary, Connie can sniff the air coming from coal and sulfuric acid when there is wind,. "the hard air was still sulphureous. Round the near horizon went the haze, opalescent with frost and smoke, and on top lay the small blue sky: so that it was like being inside an enclosure, always inside".(Lawrence, p39) Connie cannot believe that the beauty of nature is already out of the sight step by step. According to Lawrence, the country is so gloomy although is the month of May that this "gloomy" and "soulless ugliness" can be fully seen throughout the whole novel. Clouds of steam and smoke from the chimney from the pit which has been burning for many years can be seen everywhere. In addition, Connie and Clifford can smell the hard air filled with sulphur when walking across the park to the wood. Such scenery comes into her insight when Connie goes into Uthwaite one day:

... the blackened brick dwellings, the black slate roofs glistening their sharp edges, the mud black with coal-dust, the pavements wet and black. It was as if dismalness had soaked through and through everything. The utter negation of natural beauty, the utter negation of the gladness of life, the utter absence of the instinct for sharply beauty... (Lawrence, 2009, p.150)

With these descriptions of industrial black, dark villages, Lawrence presents reader an impressive image of destructed nature made by human beings, indicating his deep worry about the industrialization. That is why he hopes people could one day go back to the former Tevershall:

Tevershall! That was Tevershall! Merrie England! Shakespeare's England! No, but the England of today, as Connie had realized since she has come to live in it. It was producing a new race of mankind, over-conscious in the money and social and political side, on the spontaneous intuitive side dead, but dead. Half-corpses, all of them: but with a terrible insistent consciousness in the other half. There was something uncanny and underground about it. It was an under-world. And quite incalculable. (Lawrence, 2009, p.151)

As described: "There was nothing but a ravel of dead bracken, a thin and spindly sapling leaning here an there, big sawn stumps, showing their tops and their grasping roots, lifeless" (Lawrence, 2009, p.42). There is a scene when Connie returns to Wranby with Clifford, shocked completely that the environment people is living is like the hell.

Connie was accustomed to Kensington or the Scotch hills or the Sussex downs: that was her England. With the stoicism of the young she took in the utter, soulless ugliness of the coal-iron Midlands at a glance, and left it at what it 
was: unbelievable and not to be thought about. From the rather dismal rooms at Wragby she heard the rattle-rattle of the screens at the pit, the puff of the winding-engine, the clink-clink of shunting trucks, and the hoarse little whistle of the colliery locomotives. (Lawrence, 2009, p.14)

Following Connie to stepping into the world of a dirty and ugly Wragby, readers see a industrialized world full of machines, coal iron and smell of acid. The beauty of nature is largely destructed by the industrial business expansion. "Day and night there are the noises of the screen at the pit, the winding-engine, and the trucks" (Lawrence, 2009, p.45). The air is filled with smell of burning sculpture from the underground. The whole world is in a mess because of the burning furnaces of the colliery, with the houses and streets covered with dust from the colliery. There is no doubt that nothing is capable of escaping from the pollution caused by the industrialization. Nature is sacrificed in the process of human's unlimited pursuing for the economic profits. It is evident that human becomes the criminal who despoils the resources, leaving unrecoverable filth on the beautiful landscapes and causing the degeneration of nature. However, human gets his punishment from nature as well.

\section{Humanity Is ALIENATED}

Relationship, especially the one between men and women is one of the most significant themes in Lawrence's works. In his opinion, not only the harmony of the natural world is ruined by the industrialization, but also the harmony of human world is broken up. According to ecofeminists, there is a close connection between nature and female. As Sherry Ortner declared that "cross-culturally and historically, women, as opposed to men, have been seen as closer to nature because of their physiology, social roles, and psychology" (Ortner, 1974, p.67). Like these ecofeminists, Lawrence shares the same opinions that nature and women are similar from the historical and social perspective. On the one hand, nature is ruined by the ruthless industrialization. On the other hand, male and female, as human being, for resembling the nature, become the victims of industrialization as well.

"But didn't you say the other day that you were a conservative-anarchist,"she asked innocently. "And did you understand what I meant?" he retorted. "All I meant is, people can be what they like and feel what they like and do what they like, strictly privately, so long as they keep the form of life intact, and apparatus." (Lawrence, 2009, p.193)

From the above conversation we can feel that Clifford is superior to working class in the industrialization and treats them cruelly. As a representative of the ruling class, Clifford is presented by Lawrence as a selfish, ugly, cruel, heartless and greedy half-man, even a half-machine monster, fully demonstrating Lawrence's hatred to industrialization that leads to alienation of human beings.

In Lady Chatterley's Lover, Clifford Chatterley is a typical victim image of industrialization, with his humanity being alienated. He is wealthy and in a high social status for his own real estate and coal-mine. Unfortunately, he never stops pursuing money, fame and social position in his life. Deeply influenced by the capitalist industrialization, he gets his lager profits from the mining industry, treating the miners crucially. Clifford has become crippled and impotent after he comes back from the war, which makes him unable to have a child. His inferiority of being disabled and male sexual dysfunction can even be reduced by the feeling of surrounded by the power and his money. Undoubtedly, Clifford is a symbol of modern man has lost himself in the process of industrialization. His physical paralysis led to his mental paralysis for the highly industrialized world he lived. "The gay excitement had gone out of the war...dead. A man needed support and comfort. A man needed a wife" (Lawrence, 2009, p.8). So, after losing his male power, he chooses to marry in order to get rid of his spiritual emptiness. In his eyes, sex is not an necessary part of his marriage life, which is opposite to Lawrence's viewpoint that sex is a key for maintaining a harmonious relationship between men and women. Therefore, Clifford's asexual marriage will finally be a tragedy.

Clifford becomes a motionless animal in the process of being alienated. On the one hand, his paralysis makes him fragile. When being asked about his opinion on sex, he blushes and says that sex could only promote the mental intimacy between men and women, and it is a "habit" for a couple. "We have the habit of each other. And habit, to this thinking, is more vital than any occasional excitement." (Lawrence, 2009, p.46) Then he turns his attention to coal-mine industry, making money to escape from his inferiority as a disabled husband. His alienation is not only embodied in his marriage life, but also his cruel attitude towards working class. In order to make profit from the coal-mining industry, he squeezes every drop of productivity from the miners, leading to their dissatisfaction and strike. There are heat disagreements and argues between the couple for Clifford's cold and heartless attitude, which gradually distances Clifford and Connie. Clifford is a man who is rich materially but poor mentally. When he got his reputation, wealth and power as a modern industrialist, he tends to show off in order to hide his poor spirit. However, his such foolish concealing is doomed to a failure. "The wallowing in private emotion, the utter abasement of his manly self, seemed to lend him a second nature, cold, almost visionary, business-clever. In business he was quite inhuman." (Lawrence, 2009, p.304) Obviously, Clifford is only the poor victim of industrialization physically and mentally. Lawrence makes every effort to criticize industrialization, showing his deep concern about the human being and nature.

\section{THE CONSTRUCTION OF IDENTITY OF NATURE AND WOMAN}

In Lady Chatterley's Lover, Connie, is fascinated by nature. It is the wood that provides Connie the resort when she escapes from the gloomy family and the frustrating life with Clifford. What's more, her spirit is getting better every 
time she gets back from the wood. And she comes back looking like before: "a ruddy, country-looking girl with soft brown hair and sturdy body, and slow movements, full of unusual energy" (Lawrence, 2009, p.20) Lawrence believes that nature is a typical symbol of the whole world, in which Connie escapes from the reality. To Connie, the wood is her "Eden", awaking her physically and spiritually. It is the wood that gets rid of her despair, bringing her rest, fresh air and the beauty of the flowers and trees. The wood is like an effective medicine, curing her distorted heart. Connie is surrounded by the feeling of being empty, caged and pressed, although she is noble and wealthy. It is the wood that provides her with the freedom, peace and consolation.

Meanwhile Mellors, the gamekeeper, is also cured by the wood. After retiring, he lives in the wood, enjoying the natural air, protecting the wild lives, and witnessing the renewal and regeneration at the same time. The sacred wood is his paradise to some extent. Only in the wood can he live happily and be himself. The wood, also the safest place for Mellors, helps him to forget his suffering past. He separated himself from others until he meets Connie.

Without knowing, he came quickly towards her and crouched besides her again, taking the chick from her hands, because she was afraid of the hen, and putting it back in the coop. At the back of his loins the fire suddenly darted stronger. (Lawrence, 2009, p.113)

In addition, the wood is the place Mellors' sexual consciousness wakes up. When Connie appears in the wood, his coldness is melted and his heart is opened by Connie, who changes him from an incomplete man in to a complete man in the end.

he was aware of the old flame shooting and leaping up in his loins, that he had hoped was quiescent forever. He fought against it, turning his back to her. But it leaps downwards, circling in his knees. He laid his hand on her shoulder, and softly, gently it began to travel down the curve of her back, blindly, with a blind stroking motion. to the curve of her crouching loins. And there his hand softly, softly stroked the curve of her flank, in the blind instinctive caress. (Lawrence, 2009, p.114)

Therefore, to Connie and Mellors, the wood is their heaven. It is nature that makes them have a rebirth. Both Connie and Mellors realize that the conclusive way to work out the plight of modern society is to reconciliate with nature and to abandon the hopeless attempt to conquer nature. Nature establishes her own identity by providing both Connie and Mellors the wood.

Lawrence criticizes the tragic influence of industrialization on both body and soul of human. And the only solution to their getting back unconscious and instinctual self is to return to nature providing with human with energy to recover from the frustrating reality, which is like the pregnant mother giving nutriments to her baby. Therefore, the healing effect of nature is strongly evident. And Lawrence himself is optimistic and hopeful for that. As he said once "It is rather hard work: there is now no smooth road into the future. But we go round, scramble over the obstacle. We've got to live, no matter how many skies have fallen" (Lawrence, 2009, p.1)

Connie is shacked in her dull and lifeless life in Wragby. Only after she returns to the wild world, can she feel the essence of life. Connie establishes her identity by means of satisfying her sexual desire. Mellors plays a significant role in establishing Connie's identity. With the appearance of Mellors, Connie's innermost sexual desire is aroused. Harmonious sexual relationship is an indispensable part in human beings. There is some descriptions in the novel about Connie's awaking self-consciousness:

She had come to the real bed-rock of her nature, and was essentially shameless. She was her sensual self, naked and in ashamed. She felt a triumph, almost vainglory. So! That was how it was! That was life! That was how one really was! There was nothing left to disguise or to be ashamed of. (Lawrence, 2009, p. 245)

Connie achieves her individuality as a woman. She has the qualities of intelligence, independence and courage of changing. In a patriarchal society, Connie is brave enough to fight against injustice and pursue her equality, security and happiness. These are the reflections of her eco-feminist, struggling for the equality and freedom. Her bold pursuing for love physically and mentally saves her from the dull and empty marriage life and constructs her own identity finally.

\section{REFERENCES}

[1] Becker, Cz J. (1980). D. H. Lawrence. New York: Frederick Ungar Publishing.

[2] Harris, Janice H. (1990). Lawrence and the Edwardian Feminists .Wisconsin: The University of Wisconsin Press.

[3] Lawrence, D. H. (2009). Lady Chatterley's Lover. London: Penguin Books.

[4] Mellor, Mary. (1997). Feminism and Ecology. New York: New York University Press.

[5] Michael, S. (1983). The Creation of Lady Chatterley's Lover. Baltimore and London: Johns Hopkins University Press.

[6] Murphy, Patrick. D. (1998). Ecofeminism Literam Criticism. Illinois: University of Illinois Press.

[7] Ortner, Sherry. (1974). Is Female to Male as Nature is to Culture? Stanford: Stanford University Press.

[8] Plumwood, Val. (1993). Feminism and Master of Nature. London: Routledge.

[9] Reeve, N. H. (2004). Reading Late Lawrence. London: Palgrave Macmillan.

[10] Warren, KarenJ. (1997). Ecofeminism: Women, Culture,Nature. Bloomington: Indiana University Press.

Ting Bo was born in Jiangsu, China in 1980. She got the MA of Arts at East China Normal University, China in 2009. She was currently a lecturer in Faculty of Foreign Languages in Huaiyin Institute of Technology, Jiangsu, China. Her research interest is literature, intercultural communication, teaching method. 